\title{
When Autocracies Have No Respect for the Nobel Prize
}

\author{
BY \\ INA SHAKHRAI
}

As both the first writer and the first woman from Belarus to receive the Nobel Prize in Literature, Svetlana Alexievich became a centre of public attention worldwide. While the first tweets from the Nobel announcement room generated some confusion regarding this unknown writer from an unknown land - with about "10,000 reporters googling Svetlana Alexievich" (Brooks 2015) - the subsequent media coverage of the writer in such publications as The Guardian, The New Yorker, and Der Spiegel sketched out a broad picture of Alexievich's life, career and main works.

Meanwhile, the Belarusian state media remained reluctant to give the award much attention: the upcoming presidential elections and Lukashenka's visit to Turkmenistan took priority. In a couple of cafes and art spaces in Minsk young people gathered to watch Alexievich's speech live via the Internet. Independent and alternative websites offered platforms for discussion and the exchange of opinions. Interestingly, the general public was divided over the question of the "Belarusianness" of Alexievich. The identity of the protagonist in Alexievich's books caused a heated discussion among Russian intellectuals as well. They could hardly accept that Alexievich's works might epitomize the experience of a genuinely Soviet individual, as they set out to. There was also much speculation on whether Alexievich should be acknowledged as a Russian writer, or whether the West treated her as Belarusian in order to chastise Russia.

The events surrounding Alexievich's Nobel Prize represent a revealing example of the all-encompassing nature of autocratic political systems, as well as how confusing and interwoven national identities can be. Researcher Volha Charnysh explains the controversial reactions to Alexievich's Nobel Prize in Belarus by pointing out the growing politicisation of language choice and interpretation of history. According to her, in the Belarusian cultural sphere "both the regime's opponents and supporters alike practice the denunciation of writers who do not follow the political script" and remain "prisoners to Belarus's Soviet past and authoritarian present" (Charnysh 2015a). Moreover, contrasting reactions to Alexievich's work "reflect deepening divisions in post-Soviet space" and indicate 
the weakness of national identity in Belarus (Charnysh 2015b). Lizaveta Kasmach underlines the relevance of the role of Belarusian society, which, unlike the pro-governmental mass media and the authorities, treated Alexievich "with the appropriate recognition and respect" (2016).

This article stresses the interconnection between the current political situation in Belarus, Soviet history and the post-Soviet region. Using the case of Alexievich's Nobel Prize, it analyses how autocratic elites learn from the past, and how diffused norms shape public attitudes in neighbouring autocracies. The article assumes that the choice of the Belarusian authorities to strategically neglect Alexievich's contribution to the Belarusian cultural landscape, as well as the prevalence of nationalist discourse surrounding Alexievich's Nobel prize in both Belarus and Russia, are conditioned by the geographical proximity of Belarus and Russia and their common historical past. Therewith it contributes to research on autocracy, elaborates on the learning of autocratic practices across space and time, and expands on the knowledge of contemporary politics in Belarus and Russia. This research is based on both primary sources, such as official statements, opinion poll data, and media coverage, and secondary sources, such as analytical articles and papers.

The unusual post-modern format of Alexievich's works naturally raised many questions among scholars, writers and readers. However, this study will not discuss the literary quality and value of Alexievich's writing, leaving this task for literary critics.

The article is organised as follows: It first introduces the concept of autocratic learning. It then analyses how the perception of Alexievich's Nobel Prize by the Belarusian authorities mirrored the treatment of disloyal intellectuals in the Soviet tradition. It also elaborates on the attitudes of Belarusian civil society towards Alexievich's award. The paper then goes on to examine the diffusion of nationalist sentiment in Belarusian and Russian society, and the resulting controversial attitudes towards Alexievich as a Nobel Winner. Finally, it concludes that Alexievich has not become a unifying figure for the post-Soviet community.

\section{Autocratic Learning}

The dynamics of external-internal diffusion processes and their impact on national political regimes "have received scant attention in the literature" (Lankina and others 2016). Therefore, scholars of the new autocracy studies increasingly focus on the external dimension of authoritarianism and on the diffusion of authoritarian norms and practices across space and time. Along with the active promotion of autocracy, such issues as "regime-boosting regionalism" (Melnykovska and others 2012; Erdmann and others 2013), mutual learning among autocracies (Silitski 2010; Vanderhill 2012) or unintended autocratic impact (Obydenkova and Libman 
2015), have appeared on the research agenda. This study contributes to literature on unintentional authoritarian impact through autocratic learning.

Autocratic learning, alternatively called lesson-drawing, is a mechanism of norms diffusion, through which external actors unintentionally influence domestic political processes. Heydemann and Leenders define it as a "wave effect facilitated by the rapid diffusion of ideas, discourses, and practices from one country to another and their adaptation to local contexts" (2011, p. 648). The researchers initially applied this concept to study the protests in the Arab world in the 2010s both on the level of Arab societies and on the level of autocratic elites, focusing especially on the elites' response to social unrest. In his paper for the workshop "International Diffusion and Cooperation of Authoritarian Regimes" held in Hamburg, Germany, in 2016, Leenders fine-tuned his definition to include the notion of autocratic resilience. According to his new definition, autocratic learning should be understood as a set of "international and transnational interactions enabling the exchange or transfer of knowledge, ideas, insights, models, expertise, skills and/or technology that can be used at the service of a regime's efforts to adjust, enhance or optimize authoritarian governance" (Leenders 2016).

The analysis of autocratic learning and the unintended consequences of external influence ignores the intentions and goals of a political actor, whose mere existence can cause changes in the policies of a potential recipient. Therefore, it focuses primarily on the ability of domestic actors to watch and learn from their own historical experience and from the experience of their neighbours, and to adapt the lessons learned to local circumstances. Even if this theoretical constraint seriously limits the scope of the article, for the purpose of this research it is important to concentrate on unintentional, often unforeseen consequences, rather than on the coordinated efforts of politicians.

The process of learning, or lesson-drawing, occurs through the following processes: adoption, which is conceptualised as a direct and complete copying of foreign norms, ideas, practices or models; emulation, or an adoption with adjustments to domestic circumstances; and inspiration - a process that occurs when external norms, ideas, practices or models inspire change, but with a final outcome not drawn from foreign examples (McFaul and others 2009, 17). These lessons can be drawn from various actors, including neighbouring states, predecessor states, or leading international actors. The effectiveness of learning as an unintentional diffusion process is higher for those actors who find themselves "in geographic proximity or who share cultural or economic links" (Ambrosio 2013, 197-98). The assessment of a learning outcome is made on the basis of the references to the lessons learned, as well as adoption and adaptation facts and convergence ${ }^{1}$ of policies.

1 Convergence here involves different degrees of movement towards conformity with the pre-existing point of reference (a powerful state, a regional organization or even a community) (McFaul and others 2009, 10). 
Belarus represents a revealing case study of autocratic learning due to its geographical proximity to Russia, its Soviet past and current political regime. Recent examples of how autocratic elites in Belarus have learned from neighbouring actors include, among others, the use of the apple blossom ribbon instead of the Russian St. Georgian ribbon on Victory Day, or the copying of certain legal provisions from repressive Russian laws on mass media activity in the context of the Ukrainian crisis since autumn 2013. This article uses the specific case of the reception of Alexievich's Nobel Prize in Belarus and Russia to demonstrate both the learning effect among political elites and the diffusion of autocratic norms across communities and civil society.

\section{The Perception of Alexievich's Nobel Prize in Belarus}

\section{The Reluctance of Autocratic Elites in Belarus with Regard to the Nobel Prize}

The fact that Lukashenka, his retainers, and the official media in Belarus initially attempted to ignore or downplay the celebration of Alexievich's prize can be explained by the writer's critical stance towards current Belarusian and Russian regimes and towards their common Soviet heritage. Belarusian officials learned from the Soviet leadership's discriminatory treatment of disloyal intellectuals. In the case of Alexievich, they have taken recourse in the strategy of neglect and even tacit condemnation of the significance of Alexievich's works. Indeed, the degree of self-censorship which was reflected in the eagerness of bureaucrats and officials to pointedly ignore or deride Alexievich resembled the Soviet tradition of treating "untrustworthy" intellectuals and public figures in this way.

Why would Alexievich be perceived as disloyal or even garner comparisons with Bunin or Pasternak? First of all, her difficult relationship with Belarusian and Russian authorities has had a long history. As both a literary writer and an investigative journalist, she covered many sensitive issues such as the Chernobyl catastrophe, the Soviet war in Afghanistan, and female soldiers in WWII. Subsequent close attention from both Soviet and Belarusian authorities in regard to her personality was thus inevitable.

Consequently, Alexievich did not receive any recognition in Belarus or any Belarusian literary prizes, despite being a winner of numerous international awards, including ones from Russia and the USSR. In one of her first interviews after receiving the Nobel Prize, she complained: "The Belarusian authorities pretend that I don't exist. My books are not published, I can't speak anywhere, at least on Belarusian television" (Alexievich 2015a). Indeed, she has not been published in Belarus for almost 25 years, while 500 copies of her recent book Second-hand Time were published by a quasiunderground non-state publisher called Lohvinau (Hulpachova 2015). 
Partly in protest against the authoritarian politics of Lukashenka, partly "to save her energies for writing" (Gessen 2015), Alexievich left Belarus in 2000 and lived in France, Germany, Italy and Sweden for more than ten years. Professedly, she hoped to wait for the autocratic regime in Belarus to democratise, but unwilling to wait that long she returned to Minsk. As she put it herself: "I was wrong to think I could sit him out" (Gessen 2015).

Alexievich has made open and direct statements about her attitude to authoritarian regimes. In her last book, Second-hand Time, she created a collective image of a Soviet person with the voices of the witnesses to Soviet time. She comes to the conclusion that, as she stated later in her interviews, "the heaviest heritage of socialism is a man, a traumatised man because a camp perverts both the hangman and the victim" (Alexievich 2015a). Interestingly, in the book she "identifies explicitly (by using "we") with her own generation, "simultaneously Soviet and post-Soviet"" (Snyder 2015). In this vein, her criticism of the current regimes in Belarus and Russia is interconnected with the traumatic experience of the Soviet past.

Alexievich has called Belarus a "soft dictatorship" (Deutsche Welle 2015) and criticised Lukashenka for the absence of a political will to carry out reforms, and for his obsession with power (Govorit Moskva 2015). She has also condemned authoritarian policies in Russia (Alexievich 2015a), as well as recent political developments in the country, including, among others, the intervention in Ukraine and the annexation of Crimea (Charter97.org 2015). Despite the fact that the Russian Minister of Information was one of the first to congratulate Alexievich on her Nobel Prize, the Russian authorities have mostly ignored developments surrounding her accomplishment. The reactions of the authorities in Belarus have reflected disappointment regarding their unfulfilled expectations that as a Nobel Prize Winner, Alexievich would take advantage of her international podium to show loyalty and support for the official regime.

On 8 October 2015, several hours after the announcement of the Nobel Prize Winner in Literature, Lukashenka congratulated Alexievich (The official internet portal of the President of the Republic of Belarus 2015b). Later, during a pressconference in Berlin on 11 October 2015, Alexievich noted: "President Gauck was the first person to congratulate me, then the foreign minister, and in the evening Lukashenka congratulated me. That was a bit strange" (Ukraine Today 2015). However, this was not the only time that Lukashenka recognised the achievements of Alexievich in public. Later, when being asked about his attitude to Alexievich during a meeting with the construction workers of the Belarusian nuclear power plant, Lukashenka answered:

I'm glad for her, as she is a citizen of Belarus. The award means that, regardless of your position, you can still work and create, write, 
speak your mind and so on in Belarus. [...] I've read her thoughts in the printed media, which I daily receive. [...] In my greeting to Ms. Alexievich, I wrote that it's important that a Belarusian has won a Nobel Prize: the first time since Soviet days. The key now is how she'll use this. [...] You may be flying high, but how will you use this image, this legacy? For the benefit of your people? People should enjoy the benefit of you being fortunate enough to receive this award; we'll survive any sort of oppositional thoughts (2015b).

During an informal talk with the Swedish ambassador Oberg, Lukashenka again stressed that Alexievich didn't represent any political opposition, and ordered her books to be presented to the ambassador on his behalf (Kalesnikava 2015). The cautious benevolence of Lukashenka was clearly based on the expectation that Alexievich would use her sudden international visibility to attract positive attention to Belarus and improve its image. However, very soon Lukashenka faced Alexievich's criticism and disparagement, and the official tactics for dealing with the Nobel Prize winner changed.

The day after the conversation with the Swedish ambassador, during an event dedicated to the Russian composer Drobysh, Lukashenka spoke unfavourably about Alexievich. He accused her of pouring "a bucket of mud on the country" and called her a "bad son" of her homeland (Belsat 2015a). Since then, Belarusian officials and the state media have mostly neglected the events following her Nobel Prize win. Thus, Belarusian TV refused to broadcast the Nobel Lecture on 7 December, as well as the Nobel Prize Award Ceremony and Banquet Speech on 10 December, citing technical and financial difficulties (Belaruspartisan 2015).

The pro-government newspaper Belarus Segodnia attempted to portray Alexievich's loyal stance toward the current Belarusian authorities and published some excerpts from Alexievich's Nobel lecture, acknowledging that the scale of her achievement would in the end benefit the global image of Belarus. An unsigned editorial commentary concluded that she "was not willing to follow the lead of socalled "pseudo-democrats," which they inferred from the lack of references to any opposition slogans in her lecture (Belarus Segodnya 2015). However, already on the day after the publication of this article, Alexievich in her Banquet speech spoke in Belarusian about the autocratic policies in the country (Alexievich 2015c).

\section{Belarusian Civil Society Celebrates the Nobel Prize}

While Belarusian officials and the state media remained passive and unenthusiastic about the first Belarusian Nobel Prize winner, Belarusians themselves demonstrated an impressive level of civic self-organisation. Thus, "as a response 
to the state's disdain of Belarus's Nobel Laureate," the Facebook initiative "Let's celebrate the Nobel together!" and the hashtag \#nobelrazam were born (Kuchta 2015). In a number of cafes and art spaces in Minsk, young people gathered to watch the ceremony and Alexievich's speech live via the Internet. Independent and alternative websites offered platforms for discussion and the exchange of opinions. Around 300 people came to the National Airport to greet Alexievich when she returned from Sweden.

She also received recognition from well-known public figures. Among those who publicly supported Alexievich were - to name just a few: Jury Ziser, owner of Tut.by, Belarus's most popular online news service, the writer and politician Uladzimir Niakliajeŭ, the former presidential candidate Sannikaŭ, who wrote an article about Alexievich in The Guardian, as well as representatives of the business community, including the chairman of Belgazprombank Viktar Babaryka. An opinion poll showed that 57 per cent of Belarusian respondents saw the Nobel Prize as "a source of pride and international recognition of Alexievich's talent" (IISEPS 2015b).

This impressive number suggests a high level of recognition for Alexievich's award and its significance for society at large, despite the politically sensitive nature of Alexievich's works and the critical stance of the authorities towards the writer's public activity. At the same time, however, the remaining 43 per cent of the respondents saw things differently; almost 10 per cent of them assessed the presentation of the Nobel Prize in Literature to Alexievich as "an attempt by the West to harm Belarus and Russia". Interestingly, the Belarusian community was divided over the question of whether Alexievich should be praised and recognised as a Belarusian writer.

\section{The Diffusion of Nationalist Sentiment in the Post-Soviet Space}

The issue of Alexievich's national identity came to the forefront of public discussions together with the proliferation of nationalist sentiment across the postSoviet space. The rise of nationalist consciousness in Belarus was instigated by growing nationalism in Russia in the wake of the Ukrainian crisis that started in November 2013 with Euromaidan and led to the annexation of Crimea by Russia and military actions in southern and eastern Ukraine. The diffused elements of Russian nationalism were adapted by the Belarusian community to fit local conditions. As a result, the number of Belarusians who preferred independence, as opposed to both European and Eurasian integration projects, and valued the stability and independence of Belarus has been growing (see Kryvoi and Wilson 2015; IISEPS 2015a). Alongside these trends, the Belarusian authorities have started to promote 
national identity and unity. Thus, several steps have been taken to promote the Belarusian language (Barushka 2015), and Lukashenka has intermittently underlined the fact that Belarus is not a part of the Russian world, but an independent country (see, for instance, Kryvoi and Wilson 2015; Bohdan 2015; The official internet portal of the President of the Republic of Belarus 2015a; Lukashenka 2015a). The attitudes of the general public in Belarus to Alexievich's Nobel Prize reflect an increasing diffusion of nationalist sentiment in the post-Soviet region.

\section{The "Belarusianness" of Alexievich}

Besides the question of the literary quality of her prose, the "Belarusianness" of Alexievich has become one of the main subjects of critique in both Belarus and Russia. Belarusian critics could not but recall a provocative statement Alexievich made in Germany in June 2013, after her receipt of the Peace Prize of the German Publishers and Booksellers Association. In an interview with the German daily Frankfurter Allgemeine Zeitung, she stated that the Belarusian language is "rural and literarily unripe" (Holm 2013). This caused a wave of protest in the Belarusian media and on social networks. Subsequent statements made by Alexievich in an attempt to explain her position in more detail were even more confusing and cast "a shadow on the judgment of the famous writer" (Lashuk 2013).

Now, two years later, Alexievich has again been denounced for her attitude towards the Belarusian language and the insufficient attention she affords Belarus. For example, the newspaper Naša Niva published an article with some statistics on the words used in Alexievich's Nobel lecture, according to which the word "Belarus" was only used six times, whereas the word "Russian" was used twenty times (2015). The view that Belarusian literature should be written in Belarusian has been expressed by organisations such as the civic campaign Budźma and the Belarusian Solidarity Platform. The internet community by_mova even conducted a poll on whether Alexievich can truly be considered a Belarusian writer (Charnysh 2015a). A number of political figures, such as Zmicier Daškievič, a leader of the opposition movement, and writers such as Sviatlana Kurs and Adam Hlobus, have expressed their concerns about Alexievich's writing in Russian (see, for instance, Charnysh 2015b; Berezyuk and others 2015).

\section{Alexievich and the Russian World}

Considering Alexievich's works and awards through a prism of national identity was also characteristic of Russian public figures and mass media. Here two main trends representing two different worlds permeated by nationalist sentiment can 
be observed. First, some commentators suggested that Alexievich had become a representative of the Russian World and could become a significant inspirational figure (Kashin 2015; Gelman 2015). To explain: the "Russian World" alluded to here is a conceptual construct outside the domain of official discourse, the current political order, and conspiracy theories, and closer to the opposition, the critical electorate, and the liberal intelligentsia.

As Russian writer and critic Bykov put it, it is "not the Russian World that we keep hearing about on TV - not the world of aggression, lies and chauvinism - but the world of the struggle for truth, a world of kindness and humanness" (2015). These views to a certain extent reflect those of Alexievich, who distances herself from the Soviet and current Russian political authorities, stating: "I love a good Russian world, a humanitarian Russian world, a world which is respected by the whole world - the literature, the ballet, the great music. Yes, I love this world. But I do not love the world of Beria, Stalin, Putin, Shoigu - it's not my world" (2015a). Herewith she points out the deep dividing line between society and the authorities, which still exists in the post-Soviet space even after the collapse of the USSR, and reveals the alienation of autocratic authorities from society.

The discourse of a different set of Russian commentators also concentrated on the Russian World, this time contingent on Putin and strong power. Thus, some public figures, like the nationalist writer Zakhar Prilepin, saw the awarding of the Nobel Prize to Alexievich as a sign of acceptance of Russia's power and significance (2015). Yuri Polyakov, editor of the Russian weekly Literaturnaya Gazeta, stated: “It's a purely political act. The Nobel Prize in Literature has no relation to literature, it exists as an award to support oppositional writers. The political component comes increasingly to the fore" (Hansegard and others 2015).

Critics cited the anti-Sovietism of Alexievich and accused her of inciting hatred against Russia. Even though the coverage of Alexievich's prize in the Russian state media wasn't "comparable to the bullying campaign against Pasternak and Solzhenitsyn" after they received their Nobel Prizes, state journalists wrote according to a recognisable pattern, adapted from their Soviet forerunners (Drakokhrust 2015). To start with, some article titles were written in dry and pompous language, with examples like: "The buzz of the reactionist propaganda around the literary weed" from the Soviet Praŭda (Zaslavskij 1958) or "A literary woman of the right calibre" from the Russian Literaturnaya Gazeta (Puhnavzev 2015).

Furthermore, the way the state media in Russia criticised Alexievich sometimes amounted to ideologically loaded shaming. The content of the articles usually covered the following thematic areas: The West as an enemy, the critical stance of the author towards authorities and national history, and the poor quality of the literary work under consideration. Thus, the Russian newspaper Kultura described 
a plot, according to which the Nobel prize was awarded to a Belarusian writer criticising the Soviet past and Russian authorities in order to discredit Putin and instigate public protests (Ivanov 2015).

The suggestions that Alexievich acted as a Western political agent and promoted anti-Soviet sentiments were exploited in many articles from the state media, including Literaturnaya Gazeta (Puhnavzev 2015) and Komsomolskaya Pravda (Grishin 2015). All in all, the assessments Alexievich received from this group of commentators was revealing of the current vision of world affairs popular among the political elites in Russia. In order to strengthen national identity and legitimise the domestic autocratic regime, the authorities appeal to national memory and instrumentalise nationalist sentiments throughout society.

\section{Multiple Identities, Time and Space}

Retrospectively, Alexievich's award of the Nobel Prize in Literature involved active discussion, marked by polarised opinions and politically loaded criticism, in a number of countries. It deepened divisions between various interconnected opposites, such as the authorities and the opposition, the authorities and society, Belarusian and Russian identities, and the Soviet past and the post-Soviet present. At the same time, Alexievich, perhaps deliberately, neither evoked solidarity among any group of like-minded people, nor united any political or social force.

Having realised that Alexievich would not promote a positive image of official Belarus internationally, the Belarusian authorities attempted to underplay the significance of the Nobel Prize. Although her works, which were removed from the school curriculum in the early 2000s, will be re-integrated in the basic programme (tut.by 2015a), Alexievich is not considered by the authorities to be a loyal intellectual or a public figure capable of contributing to the legitimisation of the regime domestically or internationally. Accordingly, officials continue to pursue a strategy of disregarding her writings and her acknowledged status as a distinguished writer. Russian authorities have largely ignored Alexievich's success.

At the same time, both the choice of the Nobel Committee and Alexievich's insufficiently critical behaviour towards the autocratic regime in Belarus left the opposition in Belarus unsatisfied. Despite Alexievich's accusatory statements regarding the USSR and autocratic regimes in Belarus and Russia, as well the latter's intervention in Ukraine, she has not become a voice for the opposition, to a large extent owing to her independent and non-radical attitude to politics. In response to criticism of her Nobel Lecture from the oppositional Belarusian community, which reproached her for not highlighting the current political situation in Belarus, she noted that writers "should not make a rally of their Nobel lecture. [...] I have said 
everything, but as a writer" (Belsat 2015b). Alexievich used part of her Nobel Prize winnings to purchase an apartment in a gigantic, oligarch-funded building which to many Belarusians is a symbol of the arbitrariness and permissiveness of the autocracy. This points to Alexievich's unwillingness to become a moral authority (tut.by 2015b).

When making political statements, she often philosophically and insightfully recourses to history and social phenomena. Thus, commenting on the current political situation in Russia, she explains: "there is a collective Putin, consisting of some millions of people who do not want to be humiliated by the West [...] There is a little piece of Putin in everyone" (Donadio 2016). When being asked about her political vision of Belarus, she admitted that she is against revolution and pleaded for the invention of a Belarusian Gandhism in order to undertake necessary reforms (Alexievich 2015a). Her reference to Gandhism, signifying that she is against violent and immediate change in political power and prefers non-violent resistance and gradual peaceful reforms, once again exemplified Alexievich's measured approach to politics.

Alexievich has also faced considerable criticism and mistrust from the broad public in both Belarus and Russia because of the nationalist mood prevailing in these societies, especially since the beginning of the Ukrainian crisis. Alexievich's multiple identities and her critical stance towards the Soviet regime confuse those who actively appeal to historical continuity in their search for national identity in Belarus and Russia. Belarusian nationalists stress that by writing in Russian, Alexievich lays claim to a global - rather than Belarusian - identity and has failed to properly address the autocratic regime in Belarus during her appearances in Stockholm. Her critics in Russia complain that her books portray life in the USSR in an unfavourable light and thereby undermine the very foundation of the new Russian nationalism. There is also another country which has played a role in shaping Alexievich's identity: Ukraine, where she was born and where her win was received mostly positively (Charnysh 2015b). Thus, in her Nobel lecture, Alexievich told those listening: "I have three homes: my Belarusian land, the homeland of my father, where I have lived my whole life; Ukraine, the homeland of my mother, where I was born; and Russia's great culture, without which I cannot imagine myself. All are very dear to me" (Alexievich 2015b).

The perception of Alexievich's works and the reactions to her Nobel Prize are influenced by the processes of authoritarian learning across space and time. Within the spatial dimension, all three countries to which Alexievich is connected are neighbours, and consequently often face a spillover effect with regards to the diffusion of policies, norms and practices. In the last decade, and especially since the beginning of the crisis in Ukraine and the increasing confrontation between 
Russia and the West, playing the nationalist card and striving to crystallise and define national identity have been characteristic of the political and cultural landscape in all three countries. Given these circumstances, Alexevich's Nobel Prize has been predominantly considered in the context of growing nationalism. Despite the attempts of Russia, Belarus and Ukraine to stress the uniqueness of each of their own national identities, "the passage from Soviet state to national state was experienced by them all" (Snyder 2015). Thus, the temporal dimension connects the Soviet past and post-Soviet present, making both Russia and Belarus "nostalgic dictatorships" (Snyder 2015). Paradoxically, official Soviet nostalgia and collective Soviet memory to a large extent define the perception of Alexievich's texts about the Soviet past and the Soviet Person, the Red Man, in Belarusian and Russian societies.

Alexievich could contribute to the strengthening of national identity in Belarus and Russia with her critical approach to historical consciousness and collective memory in the post-Soviet space. Nevertheless, her writings about the Soviet past and the following transitional period, which constitute "a monument to suffering and courage in our time", according to the Swedish Academy, and which denunciate political regimes in the USSR and in post-Soviet countries, have led to her marginalisation by the current authorities in Belarus and Russia (The official web site of the Nobel Prize, n.d.). At the same time, because of Alexievich's multifaceted identity, it would be difficult for her to use her Nobel Prize to inspire and mobilise the opposition and critical public in either country due to the increasing nationalism and desire for self-determination in the region. All this prevents Alexievich from becoming a unifying figure for the post-Soviet community.

\section{Conclusion}

This article analysed how the unintended impact of autocratic learning from the past and diffusion of norms and practices among neighbouring states influences official policies and public moods. It explained the reactions in Belarus and Russia to the awarding of the Nobel Prize in Literature to Svetlana Alexievich in 2015 by pointing out the interconnection between the common Soviet past of these countries and the spread of nationalist sentiments in the post-Soviet space following the Ukrainian crisis. The study showed that Alexievich's dismissal of autocratic regimes and her multifaceted identity, which encompasses Soviet, Russian, Belarusian and Ukrainian elements, prevent her from becoming a unifying figure in the post-Soviet countries.

While this contribution mainly discussed the unintended consequences of external influences, some scholars claim that political actors can intentionally use the 
unintended impact of their policies to achieve certain objectives (see, for example, Casier 2015). In the case of Alexievich's Nobel Prize, it would be interesting to look in more detail at how and for what purpose individual politicians or political groups have attempted to manage the situation surrounding the win. It would also be worthwhile to compare the treatment of disloyal intellectuals by autocratic regimes in other regions of the world to explore both commonalities and specific features in the approaches of individual countries or groups of countries. These suggestions could be used to inform the future research agenda in autocracy studies.

\section{References}

Alexievich, S., 2015a. Available at: <https://baj.by/en/content/hour-after-nobelfull-text-sviatlana-alexievichs-press-conference $>$, [Accessed 2 February 2016].

Alexievich, S., 2015b. Nobel Lecture, Available at: <https://www.nobelprize. org/nobel_prizes/literature/laureates/2015/alexievich-lecture_en.html>, [Accessed 23 March 2016].

Alexievich, S., 2015c. Banquet Speech. Available at: <https://www.nobelprize. org/nobel_prizes/literature/laureates/2015/alexievich-speech_en.html>, [Accessed 23 March 2016].

Ambrosio, T., 2013. Authoritarian Belarus between Russia and Europe, in R. Vanderhill, and M. E. Alerpete Jr. eds., International Dimensions of Authoritarian Persistence: Lesson from Post-Soviet States, Lanham: Lexington Books, pp. 193-217.

Barushka, K., 2015. After decades of Russian dominance, Belarus begins to reclaim its language. Available at: $<$ http://www.theguardian.com/world/2015/jan/28/sp-russian-belarus-reclaims-language-belarusian>, [Accessed 20 March 2016].

Belarus Segodnya, 2015. Svetlana Alexievich: 'Pravdu nuzhno podavat', kak ona est"'. Available at: <http://www.sb.by/kultura/news/svetlana-aleksievichpravdu-nuzhno-davat-kak-ona-est.html>, [Accessed 20 March 2016].

Belaruspartisan, 2015. "Sviatkujem Nobielia razam!” Available at: <http:// www.belaruspartisan.org/life/326340/>, [Accessed 20 April 2016].

Belsat, 2015a. Lukashenka: hardly had Alexievich got Nobel Prize when she threw mud on country. Available at: <http://belsat.eu/en/news/lukashenkapra-aleksievich-ne-paspela-atrymats-nobelya-a-uzho-vylila-brud-na-krainu/>, [Accessed 20 April 2016]. 
Belsat, 2015b. One should not make rally of Nobel lecture - Svetlana. Available at: <http://belsat.eu/en/news/one-should-not-make-rally-of-nobel-lecture-svetlanaalexievich/>, [Accessed 01 September 2016].

Berezyuk, E., Kostyukevich, N., and Inanez, S., 2015. "Svetlana - proekt iskliuchitel'no samoi sebia". Kak otreagirovali deiateli kul'tury na pobedu Aleksievich. Available at: <http://news.tut.by/society/467784.html>, [Accessed 14 April 2016].

Bohdan, S., 2015. Is Lukashenka preparing for a war? Available at: <http:// belarusdigest.com/story/lukashenka-preparing-war-21232>, [Accessed 14 April 2016].

Brooks, X., 2015. Available at: <https://witter.com/xanbrooks/ status/652077445554794497>, [Accessed 04 January 2016].

Bykov, D., 2015. O prisuzhdenii Svetlane Aleksievich Nobelevskoi premii po literature. Available at: <http://echo.msk.ru/programs/beseda/1636786-echo/>, [Accessed 24 March 2016].

Casier, T., 2015. National Level: How the EU and Russia Manage Their Unintended Impact on Their Common Neighbours, in A. Obydenkova, and A. Libman eds., Autocratic and Democratic External Influences in Post-Soviet Eurasia, Farnham: Ashgate, pp. 89 - 107.

Charnysh, V., 2015a. Prisoners of authoritarianism: Alexievich and her critic. Available at: <http://belarusdigest.com/story/prisoners-authoritarianismalexievich-and-her-critics-15749>, [Accessed 04 March 2016].

Charnysh, V., 2015b. Belarus, Ukraine, Russia react to Alexievich's Nobel Prize. Available at: <http://belarusdigest.com/story/belarus-ukraine-russia-reactalexievich\%E2\%80\%99s-nobel-prize-23465>, [Accessed 04 April 2016].

Charter97.org, 2015. Svetlana Alexievich: "Putin now lives inside every Russian". Available at: <https://charter97.org/en/news/2015/5/15/151651/>, [Accessed 12 May 2016].

Deutsche Welle, 2015. Belarus literature Nobel winner Alexievich warns of 'soft dictatorship'. Available at: <http://www.dw.com/en/belarus-literature-nobel-winneralexievich-warns-of-soft-dictatorship/a-18775046>, [Accessed 2 May 2016].

Donadio, R., 2016. Svetlana Alexievich, Nobel Laureate of Russian misery, has an English-language milestone. Available at: < http:/www.nytimes. com/2016/05/21/books/svetlana-alexievich-a-nobel-laureate-of-russian-miseryhas-her-english-debut.html>, [Accessed 21 May 2016].

Drakachrust, Y., 2015. December 2015: Paradoxes of Belarusian love to Alexievich. Available at: <http://www.iiseps.org/?p=3898\&lang=en>, [Accessed 24 March 2016]. 
Erdmann, G., Bank, A., Hoffmann, B., and Richter, T., 2013. International cooperation of authoritarian regimes: toward a conceptual framework, Working Paper 229, Hamburg, GIGA.

Gelman, M., 2015. Available at: <https://twitter.com/galerist/ status/652096256639156224?ref_src=twsrc\%5Etfw>, [Accessed 21 March 2016].

Gessen, M., 2015. The memory keeper. Available at: <http://www.newyorker. com/magazine/2015/10/26/the-memory-keeper>, [Accessed 2 April 2016].

Govoritmoskva, 2015. Aleksievich ne soglasilas's kritikoi Lukashenko. Available at: <http://govoritmoskva.ru/news/56791/>, [Accessed 2 May 2016].

Grishin, A., 2015. Zhenskoie li litso u Svetlany Aleksievich? Available at: <http://www.kp.ru/daily/26443/3314068>, [Accessed 14 April 2016].

Hansegard, J., Maloney, J., and Marson, J., 2015. Nobel Prize in Literature awarded to Svetlana Alexievich. Available at: <http:/www.wsj.com/articles/ nobel-prize-for-literature-awarded-to-svetlana-alexievich-1444304784>, [Accessed 25 May 2016].

Heydemann, S., and Leenders, R., 2011. Authoritarian Learning and Authoritarian Resilience: Regime Responses to the "Arab Awakening", Globalizations, 8 (5), pp. 647-53.

Holm, K., 2013. Uns fehlt die Kultur des Glücks. Available at: <http:// www.faz.net/aktuell/feuilleton/bilder-und-zeiten/ein-gespraech-mit-derfriedenspreistraegerin-swetlana-alexijewitsch-uns-fehlt-die-kultur-desgluecks-12238217.html>, [Accessed 9 April 2016].

Hulpachova, M., 2015. Belarus bookshop braves the state to publish Nobel winner's work. Available at: <http://www.theguardian.com/world/2015/oct/19/ svetlana-alexievich-nobel-belarus $>$, [Accessed 2 March 2016].

IISEPS, 2015a. IISEPS news, 1(75). Available at: <http://www.iiseps. org/?p=1333\&lang=en>, [Accessed 4 April 2016].

IISEPS, 2015b. Results of the nation opinion poll conducted on December 2-12, 2015. Available at: <http://www.iiseps.org/?p=3919\&lang=en>, [Accessed 4 April 2016].

Ivanov, G., 2015. Zarubezhnye eksperty: "Aleksievich prosto vypolniaet zadanie Zapada". Available at: <http://portal-kultura.ru/articles/best/122813zarubezhnye-eksperty-aleksievich-prosto-vypolnyaet-zadanie-zapada/>, [Accessed 24 March 2016]. 
Kalesnikava, M., 2015. Lukashenka orders to present Alexievich's books to Swedish Ambassador. Available at: <http://euroradio.fm/en/lukashenka-orderspresent-alexievichs-books-swedish-ambassador>, [Accessed 15 May 2016].

Kashin, O., 2015. Lider nastoiashchego russkogo mira: kem mogla by stat' Svetlana Aleksievich. Available at: <https://slon.ru/posts/57652>, [Accessed 21 March 2016].

Kasmach, L., 2016. "Second-Hand" coverage: Alexievich's Nobel Prize in the Belarus' media. Available at: $<$ http://belarusdigest.com/story/\%E2\%80\%9Csecondhand $\%$ E2\%80\%9D-coverage-alexievichs-nobel-prize-belarus-media-24242>, [Accessed 04 March 2016].

Kryvoi, Y., and Wilson, A., 2015. From Sanctions to Summits: Belarus after the Ukraine Crisis. ECFR Policy Memo 132. Available at: <http://www.ecfr.eu/page/-/ ECFR_132_Belarus_(May_5_-_version_2).pdf $>$, [Accessed 4 April 2016].

Kuchta, P., 2015. Culmination. People in the airport welcomed Sviatlana Alexievich with flowers and books. Available at: <http://en.eurobelarus.info/ news/society/2015/12/17/culmination-people-in-the-airport-welcomed-sviatlanaalexievich.html>, [Accessed 1 April 2016].

Lankina, T., Libman, A, and Obydenkova, A., 2016. Authoritarian and Democratic Diffusion, Comparative Political Studies, pp. 1-31.

Lashuk, N., 2013. Svetlana Alexievich: Belarusian language is rural and literary unripe. Available at: <http://belarusdigest.com/story/svetlana-alexievichbelarusian-language-rural-and-literary-unripe-14532>, [Accessed 20 April 2016].

Leenders, R., 2016. Arab Regimes' International Linkages and Authoritarian Learning: toward an Ethnography of Counter-Revolutionary Bricolage. A memo for the workshop "International Diffusion and Cooperation of Authoritarian Regimes", held on June 8-9, 2016 in Hamburg, Germany.

Lukashenka, A., 2015a. Available at: <http://president.gov.by/ru/news_ru/ view/obraschenie-s-poslaniem-k-belorusskomu-narodu-i-natsionalnomusobraniju-11301/>, [Accessed 14 May 2016].

Lukashenka, 2015b. Available at: <http://www.sb.by/en-belarus-magazine/ economy-2/article/energy-for-the-future-3-11.html>, [Accessed 15 May 2016].

McFaul, M., Magen A., and Stoner-Weiss, K., 2009. Evaluating International Influences on Democratic Transitions: Research Guide for Case Study Authors, Center on Democracy, Development and the Rule of Law: Stanford. Available at: $<\mathrm{http}$ //fssi.stanford.edu/events/evaluating_international_influences_on_democratic_ development_authors_workshop>, [Accessed 2 August 2013]. 
Melnykovska, I., Plamper, H., and Schweickert, R., 2012. Do Russia and China Promote Autocracy in Central Asia? Asia Europe Journal, 10 (1), pp. 75-89.

Naša Niva, 2013. Jakija slovy najčasciej hučali ŭ Nobielieŭskaj lekcyi Aleksijevič? Available at: $<$ http://nn.by/?c=ar\&i=161353>, [Accessed 21 April 2016].

Obydenkova, A., and Libman, A., eds. Autocratic and democratic external influences in post-Soviet Eurasia, Farnham: Ashgate

Prilepin, Z., 2015. Svetlana Rossii! Available at: <http://izvestia.ru/ news/592832>, [Accessed 25 March 2016].

Puhnavzev, O., 2015. Literator nuzhnogo kalibra. Available at: <http://gz.ru/ article/-40-6528-14-10-2015/literator-nuzhnogo-kalibra/>, [Accessed 24 March 2016].

Silitski, V., 2010. Survival of the Fittest: Domestic and International Dimension of the Authoritarian Reaction in the Former Soviet Union Following the Colored Revolution, Communist and Post-Communist Studies, 43 (4), pp. 339-50.

Snyder, T., 2015. Svetlana Alexievich: the truth in many voices. Available at: <http://www.nybooks.com/daily/2015/10/12/svetlana-alexievich-truth-manyvoices/>, [Accessed 2 May 2016].

The official internet portal of the President of the Republic of Belarus, 2015a. Stenogramma vstrechi s predstavitelyami belorusskih i zarubeznih SMI. Available at: $<$ http://president.gov.by/ru/news_ru/view/stenogramma-vstrechi-s-predstaviteljamibelorusskix-i-zarubezhnyx-smi-10760/>, [Accessed 11 May 2016].

The official internet portal of the President of the Republic of Belarus, 2015b. Alexander Lukashenka sends greetings to Nobel Literature Prize winner Svetlana Alexievich. Available at: <http://president.gov.by/en/news_en/view/ alexander-Lukashenka-sends-greetings-to-nobel-literature-prize-winner-svetlanaalexievich-12293/>, [Accessed 15 May 2016].

The official web site of the Nobel Prize, n.d. Svetlana Alexievich - Facts. Available at: <https://www.nobelprize.org/nobel_prizes/literature/laureates/2015/ alexievich-facts.html>, [Accessed 28 May 2016].

Tut.by, 2015a. So sleduiushchego goda v shkolnykh programmakh poiaviatsia proizvedenia Svetlany Aleksievich. Available at: <http://news.tut.by/ society/467935.html>, [Accessed 19 May 2016].

Tut.by, 2015b. Svetlana Aleksievich kupila kvartiru v dome Chizha i dereviannuiu dachiu v Silichakh. Available at: <http://news.tut.by/society/495336. html>, [Accessed 19 May 2016]. 
Ukraine Today, 2015. Nobel laureate Alexievich holds press conference in Berlin. Available at: <http://uatoday.tv/society/nobel-laureate-alexievich-holdspress-conference-in-berlin-510937.html>, [Accessed 15 May 2016].

Vanderhill, R., 2012. Promoting Authoritarianism Abroad, Boulder: Lynne Rienner.

Zaslavskii, D., 1958. Shumikha reakcionnoi propagandy vokrug literaturnogo sorniaka, Pravda, No. 299 (14693), p.4. 